\title{
ICT Hindering Factors Applied in Jordan Construction Projects
}

\author{
Salahuddin Al-Shammary, ${ }^{1, *}$ Ali Abbas Ali ${ }^{2}$ \\ ${ }^{1}$ Department of Civil Engineering, Isra University, Jordan \\ ${ }^{2}$ Department of Electrical Engineering, Isra University, Jordan
}

Copyright $\bigcirc 2017$ by authors, all rights reserved. Authors agree that this article remains permanently open access under the terms of the Creative Commons Attribution License 4.0 International License

\begin{abstract}
Construction projects are complex domain, and that push the firms to use information and communication technology ICT in projects management. To determine the lack in use ICT in construction projects in Jordan, questionnaires distributed and interviews holds with experts to determine the factors effecting, then new questionnaire distributed to find the vital factors which are hindering the use of ICT as engineering practice. Conclusions are summarized and recommendations are proposed to support using ICT as new management style in construction projects.
\end{abstract}

Keywords Construction Project Management, Information and Communication Technology ICT, Hindering Factors

\section{Introduction}

Construction projects are complex domain, this may be because all sophisticated engineering services types such as civil (including environmental and structural) electrical, mechanical, and management (legal, financial and marketing, safety) must be evolved. The successful completion of construction projects is highly reliant on effective communications. Numerous information items are exchanged among various individuals and organizations temporarily brought together to execute a project. This kind of activity is undertaken constantly, but has received very little attention from researchers, [1].

The communication technology in present time becomes very advanced and available all over the world, middle east is one of the biggest culture that use and apply new technology of communication but till now the use of Information and Communication Technology (ICT) is limited in management and there is a lack of application, as engineering practices in construction projects in Jordan, and this will supposed to be research Problem statement.

According to the" 2012 global ICT rankings by the International Telecommunications Union (ITU), Jordan ranked as $11_{\text {th }}$ among 20 Arabic states that individuals using internet and has (139.1) Mobile-cellular subscriptions per
100 inhabitants, and $41 \%$ of individuals using internet", [2]. These numbers refer to a moderate infrastructure for communication and big part of community classified as technology users. But there is large gap between Middle East and other parts of the world as shown in figure below.

This rank indicates several obstacles for using (ICT) in construction projects. Cost of ICT and its appropriateness for various types of construction projects, also contract conditions which govern information exchange are the main challenge facing the firms and organization to use ICT as a default system for site management and for project management in genera.

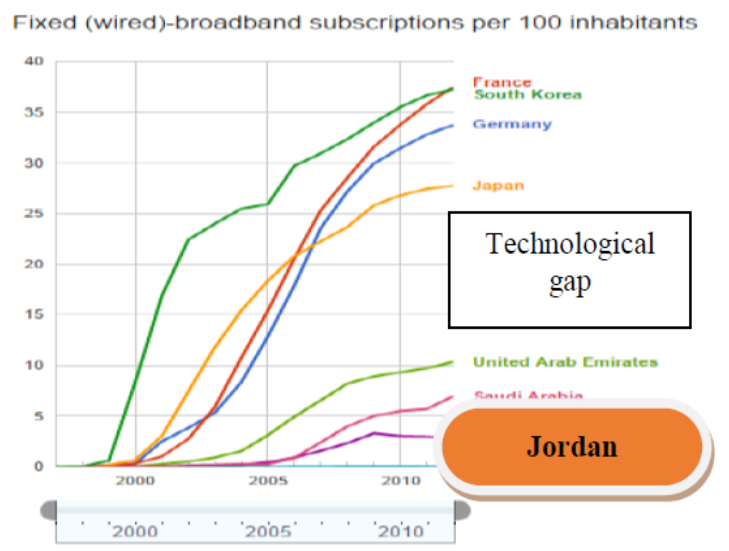

Figure 1. Communication development ranking of Jordan [2]

Some researchers found that using ICT serves the basic elements of management, "improves quality of work", makes complex tasks easier to be performed and "saves time". These elements are part of fundamental function if management which maintains a balance equal to the ribs of the triangle (cost, time and quality).

Management life cycle in any project consist of (1) prediction of implementation, (2) planning, (3) recording data, (4) comparing results, (5) controlling and monitoring, (6) feeding back. One or more of life cycle elements are implemented in each phase of Construction project which consist of five phases and each phase has special ICT device to meet requirements. These phases are (1) inspection, (2) planning and definition, (3) design, (4) procurement and 
construction and (5) startup and commissioning. [3].

There are several limitations, which can be briefly summarized as:

1. The study covered only selected area in Jordan (Amman, Zarqa, Aqaba, Irbid and Karak), but more focus was given to Amman (the capital) because most of big projects are there.

2. Since Jordan is a developed country, there are limited large scale private and governmental construction projects.

\section{Previous Researches}

Serpell, (2007), investigated the state of ICT in the Nigerian construction industry to highlight the level of ICT penetration, its impact in the industry and the constraints to its adoption. The study identified the factors significantly impacting the level of ICT use, grouping them into those internal and external to the industry. The results showed that some internal factors, i.e., the type of business (whether contracting, consulting or academic), chief executive officers (CEOs)/senior managers' perception of the benefits of ICT and the years of computer literacy of the CEOs/senior managers were significantly correlated with the level of ICT use in the industry. However, none of the external factors were significantly correlated with the level of ICT use. The main uses of ICT in the industry are word processing, Internet communications, costing and work scheduling. The top five constraints to the use of ICT are insufficient/irregular power supply, high cost of ICT software and hardware, low job order for firms, fear of virus attacks and high rate of obsolescence of ICT software and hardware. A comparison with the results of similar studies in some industrialized countries indicated that the proportion of firms using the computer is quite high for developing countries like Nigeria, [4].

Murray (2001) expected that these results will guide policymakers in Nigeria and other developing countries to identify where to concentrate their efforts to promote increased use of ICT, especially in the construction industry. In this regard, for example, maximum results could be achieved through a combination of improvement in ICT infrastructure and the education of decision makers on the benefits ICT. While it might appear too late to change the attitudes of most present-day decision makers, increased investment in ICT education in the developing world today could produce the future crop of leaders who will ensure optimum use of ICT system in their organizations, [5].

Ruikar (2005) showed that Turkish architecture, engineering, and construction (AEC) companies failed to obtain the full benefits of the visualization tools implemented though they were aware of its importance. This failure was due to the lack of user-oriented approaches and research and development efforts in implementing the visualization tools. These findings were the motivation for the second stage of the research. Moreover, the researcher determined the data flows that can be visualized to a general extent and the level of visualization necessary for meeting user requirements and expectations, in view of priorities for each of these data flows, using a quality function deployment (QFD) approach, [6].

Arjen Adriaanse, (2010). This explorative research resulted in a theoretical model that contains four key categories that explains the way actors use ICT in construction projects: (1) personal motivation; (2) external motivation; (3) knowledge and skills; and (4) acting opportunities. The model was compared with three existing influential models about the adoption and use of ICT: the unified theory of acceptance and use of technology, the theory of planned behavior, and the technology acceptance model. In addition, it is found that fundamental characteristics of construction projects, such as the fragmented and temporarily nature of construction projects, and the different working practices, resources, and objectives of the organizations involved cause most of the barriers to the intended use of inter-organizational ICT, [7].

N. B. Kasim (2010) categorized materials management into 5 processes, namely planning, procurement, logistics, handling, stock and waste control processes. It was gathered that present manual materials management and control procedures were unsatisfactory as they were labor intensive, inaccurate and error prone. The implication lead to waste and surplus of materials, delays, decrease in productivity and lack of up-to-date and real-time information. Based on the first objective in studying the implementation of ICT in materials management, the main tools that are widely adopted by the respondents are the Microsoft Offices and handheld devices. Subsequently, planning and procurement are the materials management processes considered needing the highest investment of ICT implementation. Evidently, bar-coding and RFID are tools that are hardly adopted in the materials management of each respondent's company, [8].

The data are collected through distribution of open and close ended questions lists that used for interviewing and questionairing over a group of experts, contractors, consultant engineers, owners, government employee who have been working in the international, national and governmental investment construction projects. See table 1 below.

Table 1. Questionnaire distribution

\begin{tabular}{|c|c|c|c|c|}
\hline $\begin{array}{c}\text { size } \\
\text { Project } \\
\text { type }\end{array}$ & $\begin{array}{c}\text { Big } \\
\text { Projects }\end{array}$ & $\begin{array}{c}\text { Medium } \\
\text { Projects }\end{array}$ & $\begin{array}{c}\text { Small } \\
\text { Projects }\end{array}$ & $\begin{array}{c}\text { Total } \\
\text { number }\end{array}$ \\
\hline $\begin{array}{c}\text { International } \\
\text { investment } \\
\text { Projects } \\
\text { Project } \\
\text { managers } \\
(5) \text { Site } \\
\text { engineers }\end{array}$ & $\begin{array}{c}\text { (4) } \\
\text { Project } \\
\text { (3) Site } \\
\text { engineers }\end{array}$ & - & 8 \\
\hline $\begin{array}{c}\text { Local } \\
\text { investment } \\
\text { Projects }\end{array}$ & - & $\begin{array}{c}(1) \\
\text { Project } \\
\text { manager } \\
(2) \text { Site } \\
\text { engineers }\end{array}$ & $\begin{array}{c}\text { (7) } \\
\text { Project } \\
\text { managers } \\
\text { engineers }\end{array}$ & 8 \\
\hline $\begin{array}{c}\text { Governmental } \\
\text { Projects }\end{array}$ & - & $\begin{array}{c}\text { (3) } \\
\text { Project } \\
\text { managers } \\
\text { (5) Site } \\
\text { engineers }\end{array}$ & $\begin{array}{c}\text { Project } \\
\text { managers } \\
(11) \text { Site } \\
\text { engineers }\end{array}$ & 16 \\
\hline
\end{tabular}


Results that have been collected from the private and the government sectors are compared to know the difference between the two sectors in the use of ICT in projects and to conclude which sector is more interesting to use ICT.

Moreover, private projects uses more ICT components than the governmental projects, the following table shows the percentage of ICT components used according the repliers answers.

Table 2. ICT components used in construction projects ICT components used in construction projects

\begin{tabular}{|c|c|c|c|c|c|}
\hline No. & $\begin{array}{c}\text { component } \\
\text { type }\end{array}$ & $\begin{array}{c}\text { private } \\
\text { Sector } \\
\text { replies }\end{array}$ & $\begin{array}{c}\text { \% of } \\
\text { priv. }\end{array}$ & $\begin{array}{c}\text { Government } \\
\text { Sector replies }\end{array}$ & $\begin{array}{c}\text { \% of } \\
\text { gov. }\end{array}$ \\
\hline 1 & laptop & 16 & $100 \%$ & 12 & $75 \%$ \\
\hline 2 & GPS & 6 & $37 \%$ & 2 & $12 \%$ \\
\hline 3 & GIS & 4 & $25 \%$ & 1 & $6 \%$ \\
\hline 4 & H.D & 2 & $12 \%$ & 1 & $6 \%$ \\
\hline 5 & PDA & 4 & $25 \%$ & 2 & $12 \%$ \\
\hline 6 & $\begin{array}{c}\text { Monitoring } \\
\text { cam }\end{array}$ & 4 & $25 \%$ & 2 & $12 \%$ \\
\hline 7 & RFID & 1 & $6 \%$ & 1 & $6 \%$ \\
\hline 8 & WiFi & 16 & $100 \%$ & 15 & $90 \%$ \\
\hline 9 & MS Office & 16 & $100 \%$ & 16 & $100 \%$ \\
\hline 10 & primavera & 4 & $25 \%$ & 3 & $18 \%$ \\
\hline 11 & $\begin{array}{c}\text { web based } \\
\text { software }\end{array}$ & 2 & $12 \%$ & 0 & $0 \%$ \\
\hline
\end{tabular}

From table 2 above we can see that private sector is interested to use ICT more than governmental sector, some projects have special requirement and need special ICT tools and that motivate to invest more money and effort to improve systems and software serves this projects. Though it can be observed that using of cams was limited to security purposes, there are many advantages for smart cams in tracking and measuring quantities directly and that it is very helpful for quantities surveyors and quality control engineer, but most firms were suspicious about the effective results that achieved by cams and prefer traditional survey methods.

In order to examine the feedback of questionnaire, the researcher selected two projects as a case study, both have the same environments but one of them uses ICT tools more than the second project. The researcher spent 3 months with work team observing and monitoring how they manage the tasks since they receive the tasks from senior planning engineer until delivering it to the client. All notes were recorded and compared with feedback of repliers to see the conflict and explain the real behavior of the work team at site and finally to determine the factors effecting the use of ICT in project site.

\section{A. General Hindering Factors}

From the above mentioned questionnaire and personal observations. The major factors which affect the use of ICT in construction project management in Jordan are retrieved as:

1. Cost of ICT and its components.
2. Experience years of the project managers and work teams.

3. Training to use ICT and its tools.

4. Strategic planning to inject ICT in project management

5. Specific contract's conditions to use ICT in projects and government policy.

6. Culture of community and its effect in using ICT as engineering practices.

7. ICT software limitations in construction projects.

Five interviews were conducted with experts in construction projects management from several types (small, medium and big projects) in both private and governmental projects to cover all types of environments that may affect the behavior of persons involved in construction projects These questions were designed to be open end and the respondents were given the freedom to express their opinions about issues. The interviews result is summarized as below:

1- ICT Cost: all of repliers confirmed that ICT is not expensive and the total cost for applying it will never effect on profit of project.

2- Years of experience: all repliers confirmed that the experience is an important factor helping the engineer either at site or at office to select the suitable devices for the specific task.

3- Training to use ICT: all o repliers confirmed that training is very important and to make the firm updated, but not all firms apply this concept.

4- Strategic planning: most of repliers confirmed that firms try to make strategy for using ICT but frankly they were ideal in their answers

5- Contract's conditions: all repliers confirmed that contract's conditions govern all parties which are involved in project and it is an essential factor that affects the use of ICT in construction projects. Also government policy is very helpful in directing and forcing all firms to adopt ICT in management facility and to change the related conditions of legal exchange of information and documents. It's expected to find some rejection but for long term all parties find that applying ICT will improve the standard of performance (quality, time and cost).

6- Culture of community: all repliers confirmed that culture is a real factor affecting the behavior of persons either at site or at home and finally familiarity of using ICT in construction projects.

7- ICT specific software: most of repliers confirmed that using kind of software to manage the construction project's site will be very helpful and better than traditional method for management, but it need several requirements to succeed in this mission and that depending on the firms itself and type of the system.

\section{B. Vital Hindering Factors}

Specific questionnaires were conducted for 32 project managers in both private and governmental sectors. Results were tabulated as in table 3 below and analyzed using Pareto 
chart (Fig. 2) to determine the vital hindering factors.

It is clear from Pareto table and diagram shown below that the different factors play a role in hindering the use of ICT in construction management, but among them, there are two vital factors:

1. The first factor, EDM software limitation of ICT in construction project,

2. The second factor, specific contract conditions to use ICT in construction projects and government policy.

Table 3. PARETO table

\begin{tabular}{|c|c|c|c|c|}
\hline No. & Factor & $\begin{array}{c}\text { Frequency } \\
\text { (F) }\end{array}$ & $\begin{array}{c}\text { Cumula. } \\
\text { F }\end{array}$ & $\begin{array}{c}\text { \% cumula } \\
\text { F }\end{array}$ \\
\hline 1 & $\begin{array}{c}\text { EDM software } \\
\text { limitations }\end{array}$ & 11 & 11 & $34 \%$ \\
\hline 2 & $\begin{array}{c}\text { Specific contract's } \\
\text { conditions and } \\
\text { government policy }\end{array}$ & 7 & 18 & $56 \%$ \\
\hline 3 & Strategic planning & 5 & 23 & $72 \%$ \\
\hline 4 & ICT Cost & 4 & 27 & $85 \%$ \\
\hline 5 & Experience years & 2 & 29 & $91 \%$ \\
\hline 6 & Training to use ICT & 2 & 31 & $97 \%$ \\
\hline 7 & community Culture & 1 & 32 & $100 \%$ \\
\hline & Total & & 32 & \\
\hline
\end{tabular}

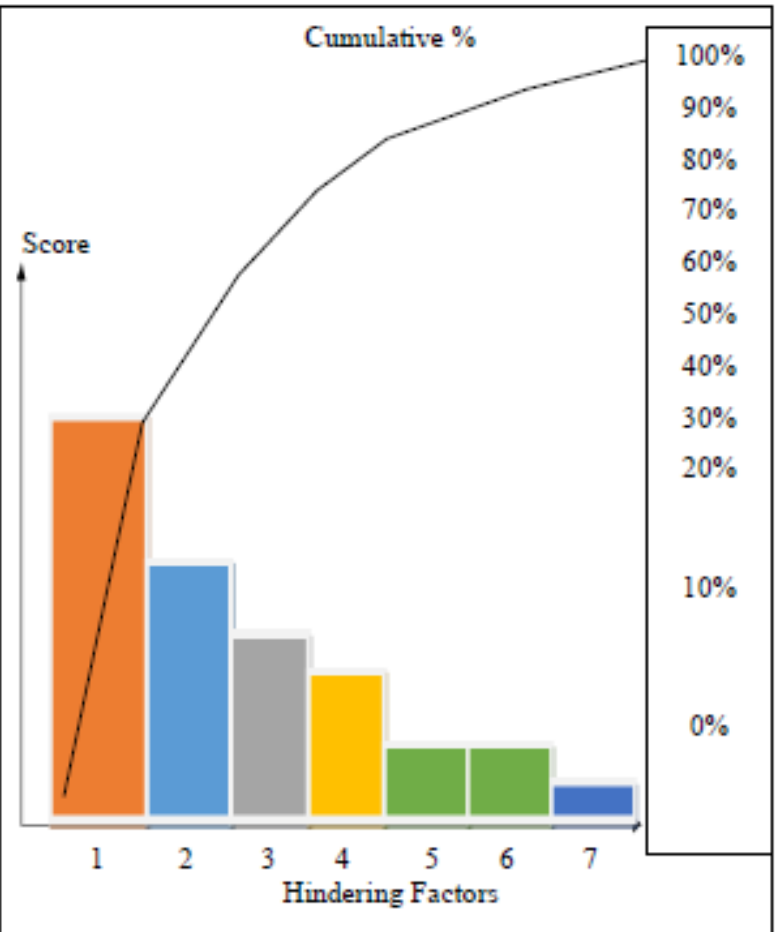

Figure 2. PARETTO diagram

\section{Analysis Results}

Results from the second questionnaire replies are statistically analyzed to get the mean of factors repetition frequency taking into account the project size and type using
SPSS package.

\section{A. Relationship between Size of Project and Hindering Factors}

The hindering factors distributions according to project's size are drawn as shown in Fig 3 below, from which the following indications can be retrieved:

- EDM limitation of ICT factor concentrated in big and medium projects.

- Legal conditions factor concentrated in medium and small project.

- Cost of ICT factor concentrated in small project only.

- Strategy of use ICT factor concentrated in medium projects only.

- Training factor concentrated in medium project only.

- Experience of PM factor concentrated in small project only.

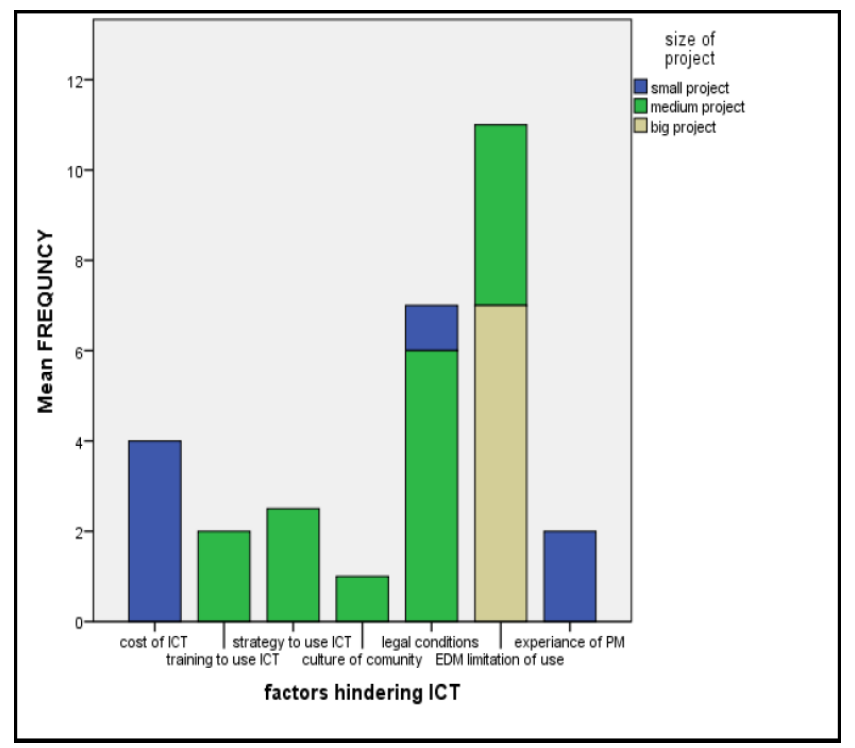

Figure 3. Hindering factors distribution according to project's size

\section{B. Relationship between Type of Project and Hindering Factors}

Again using SPSS package, the results from the second questionnaire replies are statistically analyzed to get the relationship between the mean of factor repetition frequency with the project type as shown in Fig 4 below, from which the following indications can be retrieved:

- $\quad$ EDM limitation factor of ICT got the highest frequency mean in both private and governmental project.

- Legal conditions factor concentrated in privet and governmental sector and it is in private sector more than governmental sector.

- $\quad$ Cost of ICT factor concentrated in privet sector only.

- $\quad$ Strategy of use ICT factor concentrated in privet and governmental sectors

- Training factor only in privet sector and experience factor only in governmental sector. 
- Culture of community factor only in privet sector.

- The vital factors are first and second factors of Pareto table (3.9) which represent $56 \%$ of respondent's answers.

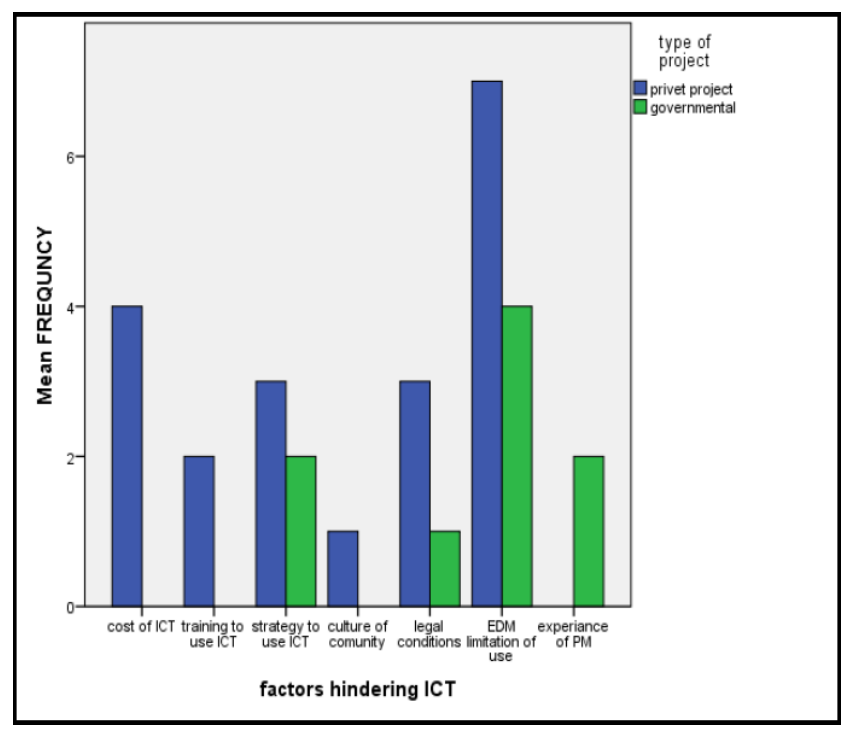

Figure 4. Distribution of factors according project type

\section{Results Discussions}

1- Limitations of ICT application in construction projects: This factor was vital and achieved (11/32) score and this represent concerning of project manager regarding the efficiency of ICT at project site. Loosing Wi-Fi signal, bad coverage of net, sustainability of service, complexity of devices and unauthorized access to system are the most barriers concerning project managers. Remove this barriers will encourage decision maker to adopt the use of ICT devices.

2- Specific contract's conditions to use ICT in projects and government policy: This factor is also very important. it achieved (7/32) and should be given real attention. Most projects, even small size ones, are executed as contract which govern by conditions that fix responsibilities and rights. So, to motivate the use of ICT, the contract must include specific conditions that support using EDM or output of ICT devices.

3- Other factors: Strategic planning to inject ICT in project management achieved (5/32), Cost of ICT and its components achieved (4/32), Experience years of the project managers and work team achieved (2/32), Training to use ICT and its tools achieved (2/32) and the effect of community culture on using ICT as engineering practices achieved (1/32). All these factors have moderate attention.

Statistical parameters: according SPSS application we can determine the following parameters
Statistics

\begin{tabular}{|c|c|c|c|}
\hline \multicolumn{2}{|c|}{} & size of project & factors hindering ICT \\
\hline \multirow{2}{*}{$\mathrm{N}$} & Valid & 32 & 32 \\
\cline { 2 - 4 } & Missing & 0 & 0 \\
\hline \multicolumn{2}{|c|}{ Mean } & 1.97 & 4.31 \\
\hline \multicolumn{2}{|c|}{ Mode } & 2 & 5 \\
\hline \multicolumn{2}{|c|}{ Std. Deviation } & .695 & 1.822 \\
\hline \multicolumn{2}{|c|}{ Range } & 2 & 6 \\
\hline
\end{tabular}

From above parameters we can assume the following formula to evaluate the judgment of the sample

$\mathrm{F}=\left(\mathrm{Mo}_{\mathrm{q}}+2 \mathrm{Mo}_{\mathrm{s}}+3 \mathrm{Mo}_{\mathrm{e}}\right) / 6$

Where:

$\mathrm{F}=$ factor rank

$\mathrm{Mo}_{\mathrm{q}}=$ mode of questioners for primary stage

$\mathrm{Mo}_{\mathrm{s}}=$ mode of reply for site engineers in secondary stage

$\mathrm{Mo}_{\mathrm{e}}=$ mode of reply for experts

\section{Conclusions}

The research has come out with the following conclusions remarks:

1- There is a large gap in Jordan to make use of the ICT in project's site management as a default engineering practices. 2- ICT is an inexpensive and flexible solution for construction problems in collaborative projects

3- There are 3 layers of ICT dealers. The first layer is eager to use ICT in construction projects. The second layer is of moderate acceptance to application of ICT which is governed by contract conditions. Finally, the third layer rejected the concept of using ICT and prefers traditional management method.

4- Government doesn't make enough efforts to encourage the firms to use ICT in construction projects although decision maker convinced that ICT will be a future tool to make development but change resistance is still facing updating.

5- The output of ICT was very persuading to achieve at least 2 of the management's elements, reduction final cost of project and decreasing time of project while keeping the high quality.

6- Overcoming all technical and logistical limitations of ICT then the decision maker will be motivated to change the roles and change contract conditions to the default application of ICT in construction project. Also that will improve strategic planning and inject new types of devices in project's site which in turn increases experience of users and finally will be reflect on community culture.

\section{REFERENCES}

[1] Jinyue Zhang and Tamer E. El-Dirabyl (2009), SSWP: A Social Semantic Web: Journal Of Computers, Vol. 4, No. 4, 330-332. 
[2] www.itu.int/icteye, (2012), United Nations specialized agency for information and communication technologies -ICT's (2012), individual using the internet.

[3] Darold D. Oberlender (2000), "project management for engineering and construction", second edition, pp. 36-44

[4] A. Serpell and S. V. Barai (2007), "An Investigation into the Use of ICT in the Nigerian Construction Industry", IT con. Vol. 12 (2007), Oladapo, pg. 261- 265

[5] Murray M., Nkado R. \& Lai A. (2001), "The integrated use of information technology in the construction industry", Proceedings of the CIB 78 Conference: IT in Construction in Africa, Pretoria, South Africa, 39-1 to 39-13
[6] Ruikar, K., Anumba, C. J., and Carrillo, P. M. (2005), "End user perspectives on use of project extranets in construction organizations." Eng., Constr., Archt. Manag., 12 (3), 222 235 .

[7] Arjen Adriaanse1, Hans Voordijk2, and Geert Dewulf3 (2010), "Adoption and Use of Inter-organizational ICT in a Construction Project", DOI:

10.1061/(ASCE)CO.1943-7862.0000201.

[8] N. B. Kasim and Peniel Ang Soon Ern (2010), "The Awareness Of ICT Implementation For Materials Management In Construction Projects", Int. J. of Computer and Communication Technology, Vol. 2, No. 1 